\section{Effects of a Gardening Program on the Academic Progress of Third, Fourth, and Fifth Grade Math and Science Students}

\author{
A.E. Pigg ${ }^{1}$, T.M. Waliczek ${ }^{2}$, and J.M. Zajicek ${ }^{3}$
}

AdDITIONAL INDEX wORDs. school gardens, science achievement, TEKS

Summary. Science and math achievement scores of third, fourth, and fifth grade elementary students were studied using a sample of 196 students from McAuliffe Elementary School, located in McAllen, Texas. The experimental group of students participated in a school garden program in addition to traditional classroom-based math and science methods, while students within the control group were taught math and science using only traditional classroom-based methods. No statistically significant differences were found in comparisons of science students' achievement scores, indicating that those students using the school garden program as an additional method to learn science benefited similarly to those who learned using only traditional science classroom-based instruction. However, results indicated statistically significant differences in comparisons of students' math achievement scores, showing that those students who received traditional math instruction had more improved math achievement scores compared to those taught using the school garden program. Results also found no statistically significant differences between gender and ethnic background comparisons. However, statistically significant differences in comparisons of grade levels showed that fourth graders benefited more, academically, from participation in the school garden program in comparison to other grade levels.

S cience and math education in the United States has been receiving attention because of a lack of effectiveness in teaching these subjects within our current school system [American Association for the Advancement of Science (AAAS), 1990; National Center for Education Statistics, 2003]. Reasons for hindrances to student learning in these areas appear to be at least partially due to a lack of interest in a subject matter thought to be dull (AAAS, 1990), and a disconnect of the subject matter with actual life events (Driver et al., 1996). This disinterest in the subjects of science and math and the lack of the ability to connect the subject matter with "real life" are disconcerting, because research has indicated that young children who participate in learning within these subject areas are more likely to be literate in these areas as adults (Loucks-Horsley et al., 1990). Math and science require hands-on activities that apply to real world problems, collection of data, analyzing data, solving problems, and using information learned in new situ-

\footnotetext{
${ }^{1}$ Research Assistant, Department of Agriculture, Texas State University, San Marcos, TX 78666.

${ }^{2}$ Associate Professor of Horticulture, Texas State University, San Marcos, TX 78666.

${ }^{3}$ Professor, Department of Horticultural Sciences, Texas A\&M University, College Station, TX 77843-2133.
}

ations (Klemmer et al., 2005; National Research Council, 1996).

Gardening programs have been a part of school curricula in various capacities for decades (Bassett, 1979; Montessori, 1912). Research has recently revolved around the use of gardens to teach topics such as science, math, nutrition, and environmental education using "real life" experiences and hands-on techniques (Eames-Sheavly, 1999; Lineberger and Zajicek, 2000; Skelly and Zajicek, 1998; Waliczek et al., 2003). Some studies have shown that outdoor experiences in the garden can help promote higher-level thinking and understanding of concepts within science and math achievement. areas such as science (Markle, 1991; Waliczek et al., 2003). Teachers report that gardening increases students' science scores and improves their overall academic achievement (Braun et al., 1989), but evaluation of science and math test scores after participation in a gardening curriculum has been limited (Klemmer et al., 2005). The problem that was addressed in this research project was whether a school gardening program would have an effect on the science and math achievement scores of third, fourth, and fifth grade students.

\section{Materials and methods}

The sample used for this study included third, fourth, and fifth grade students from McAuliffe Elementary School in McAllen, Texas. McAuliffe Elementary School was chosen because it had an accessible sample population of students with teachers that were recently trained in using the gardening curriculum by the local County Extension Service. Students were assigned to the control and experimental groups based on whether their teachers were using the gardening curriculum in their classes. The experimental group of students participated in a school garden program in addition to traditional classroom-based math and science methods, while students within the control group were taught math and science using only traditional classroom-based methods. The final sample included 196 students, with $52 \%$ (102) of the population contributing to the control group, and 48\% (94) making up the experimental group (Table 1).

Math achievement was measured using the Texas Assessment of Knowledge and Skills (TAKS). The TAKS purports to assess student achievement

Table 1. Experimental assignments and grade level of participants in a study of the influence of school gardening on

\begin{tabular}{lcc}
\hline $\begin{array}{l}\text { Participant } \\
\text { group }\end{array}$ & $\begin{array}{c}\text { Sample size } \\
\text { (no. participants) }\end{array}$ & $\begin{array}{c}\text { Sample size } \\
\mathbf{( \% )}\end{array}$ \\
\hline Experimental group & 94 & 48 \\
$\quad$ Third grade & 26 & 14 \\
Fourth grade & 24 & 12 \\
Fifth grade & 44 & 22 \\
Control group & 102 & 52 \\
Third grade & 34 & 17 \\
Fourth grade & 11 & 6 \\
Fifth grade & 57 & 29 \\
Total sample population & 196 & 100
\end{tabular}


of the Texas Essential Knowledge and Skills (TEKS), the state's curriculum (Texas Education Agency, 2005). Science achievement was measured using a previously developed test instrument that was known to be reliable $(P=0.82)$ and valid (Klemmer et al., 2005). Teachers administered the TAKS and science achievement tests to students at the end of the spring semester, after the garden curriculum had been implemented throughout the fall and spring semesters, and provided demographic information regarding study participants.

The youth gardening curriculum was developed by the Texas Agriculture Extension Service (TAES) and was intended to educate youth about horticulture, health, nutrition, environmental science, and leadership (TAES, 2001). The curriculum is a three-level program, but this study used Level 1, which is targeted to the third, fourth, and fifth grades. To ensure that the school gardening curriculum supported Texas curriculum standards, activities from the Level 1 Teacher/Leader Guide were correlated to the TEKS objectives (TAES, 2001). The gardening curriculum was taught by individual teachers of each participating classroom who incorporated the program into their curriculum to the fullest extent possible, as they would for any new teaching method being adopted by the school district. The timetable in which they offered the lessons was at the discretion of individual teachers. A garden and a very small greenhouse were maintained on campus, but the reported use of the facilities in teaching the lessons varied among teachers.

\section{Results and discussion}

Overall, results indicated no statistically significant differences between the experimental and control groups in the area of science achievement, indicating that the experimental group participating in the school gardening program learned science similarly to the control group receiving traditional classroom instruction (Table $2)$. However, statistically significant differences were found in comparisons of the means of the experimental and control groups' math TAKS scores. Students in the control group scored 4.13 points higher than the students in the experimental group, indicating that traditional math lessons were more ef- fective at teaching math concepts when compared to the gardening curriculum being used as an supplement to learn math in this study (Table 2).

Outdoor programs have been used historically to promote learning in a variety of disciplines, including math (Bachert, 1976; Montessori, 1912; Skelly and Bradley, 2000). Educators have reported that these outdoor learning experiences result in higher scores not only in science, but also in overall academic achievement (Braun et al., 1989; Stetson, 1991).

The curriculum used for this study is a school or youth gardening curriculum developed by TAES (2001). The school gardening curriculum is intended to educate youth about horticulture, health, nutrition, environmental science, and leadership. However, the subject of math was not included within the particular curriculum for Level 1 used for this study. The mean math TAKS scores of this study suggest that a gardening curriculum that focuses more on the subject of math, as well as other subjects, may be needed for improving math scores.

In demographic comparisons, males and females benefited similarly

Table 2. Analysis of variance comparing mean science and math achievement scores of experimental and control groups in a study of the influence of school gardening on math and science achievement among third, fourth, and fifth grade students.

\begin{tabular}{lcccccc}
\hline $\begin{array}{l}\text { Participant } \\
\text { group }\end{array}$ & $\begin{array}{c}\text { Sample size } \\
\text { (no. participants) }\end{array}$ & $\begin{array}{c}\text { Mean score } \\
(\mathbf{0}-\mathbf{4 0} \text { scale) }\end{array}$ & SD & df & F & $P$ \\
\hline $\begin{array}{l}\text { Science scores } \\
\quad \text { zxperimental }\end{array}$ & 94 & 22.30 & 4.981 & 1 & 1.675 & 0.197 \\
$\quad$ Control & 102 & 23.40 & 6.677 & & & \\
$\quad \begin{array}{l}\text { Math TAKS scores } \\
\quad \text { Experimental }\end{array}$ & 94 & 26.01 & 7.606 & 1 & 13.285 & $0.000^{*}$ \\
$\quad$ Control & 102 & 30.14 & 8.124 & & & \\
\hline
\end{tabular}

${ }^{2}$ Students received a raw score on the test instrument ranging from 0 to 40 based on their answers with each correct answer receiving one point.

TAKS $=$ Texas Assessment of Knowledge and Skills

*Significant at $P \leq 0.05$

Table 3. Analysis of variance comparing the mean science and math achievement scores of females and males in a study of the influence of school gardening on math and science achievement among third, fourth, and fifth grade students.

\begin{tabular}{|c|c|c|c|c|c|c|}
\hline $\begin{array}{l}\text { Participant } \\
\text { group }\end{array}$ & $\begin{array}{c}\text { Sample size } \\
\text { (no. participants) }\end{array}$ & $\begin{array}{l}\text { Mean score } \\
(0-40 \text { scale })^{\mathrm{z}}\end{array}$ & SD & df & $\mathbf{F}$ & $P$ \\
\hline \multicolumn{7}{|c|}{ Science scores ${ }^{z}$} \\
\hline Females & 96 & 22.89 & 5.386 & 2 & 0.002 & 0.998 \\
\hline Males & 98 & 22.85 & 6.504 & & & \\
\hline \multicolumn{7}{|c|}{ Math TAKS scores ${ }^{y}$} \\
\hline Females & 95 & 27.81 & 8.067 & 2 & 1.431 & 0.242 \\
\hline Males & 97 & 28.31 & 8.192 & & & \\
\hline Total & 192 & & & 193 & & \\
\hline
\end{tabular}

${ }^{z}$ Students received a raw score on the test instrument ranging from 0 to 40 based on their answers with each correct answer receiving one point.

tTAKS $=$ Texas Assessment of Knowledge and Skills.

from the gardening curriculum (Table observed in comparisons of the par ticipants by grade. Third grade control treatment group students scored on the science achievement exam. Findings suggested that when learning science, fourth grade students who in the gardening program the school gardening program to their traditional lessons when compared to only in traditional science lessons $(P$ $=0.012$ ) (Table 4). Fourth grade experimental group science achievehigher when compared to the fourth grade control group science achieveachievement mean scores could be considered somewhat low since they made mainly considering whether the gardening curriculum appeared to influence learning differently when than if students were making adequate progress overall. No differences were . 
Table 4. Analysis of variance comparing mean science and math achievement scores $^{\mathrm{z}}$ of experimental and control groups within grade levels in a study of the influence of school gardening on math and science achievement.

\begin{tabular}{|c|c|c|c|c|c|}
\hline $\begin{array}{l}\text { Participant } \\
\text { group }\end{array}$ & $\begin{array}{c}\text { Sample size } \\
\text { (no. participants) }\end{array}$ & $\begin{array}{l}\text { Mean score } \\
(0-40 \text { scale })^{\mathrm{z}}\end{array}$ & df & $\mathbf{F}$ & $P$ \\
\hline \multicolumn{6}{|c|}{ Third grade science } \\
\hline Experimental & 26 & 20.92 & 1 & 0.018 & 0.894 \\
\hline Control & 34 & 21.09 & & & \\
\hline \multicolumn{6}{|c|}{ Third grade math } \\
\hline Experimental & 26 & 30.58 & 1 & 1.764 & 0.189 \\
\hline Control & 34 & 27.92 & & & \\
\hline \multicolumn{6}{|c|}{ Fourth grade science } \\
\hline Experimental & 24 & 24.21 & 1 & 6.985 & $0.012^{*}$ \\
\hline Control & 11 & 19.27 & & & \\
\hline \multicolumn{6}{|c|}{ Fourth grade math } \\
\hline Experimental & 23 & 28.17 & 1 & 0.025 & 0.875 \\
\hline Control & 11 & 27.64 & & & \\
\hline \multicolumn{6}{|c|}{ Fifth grade science } \\
\hline Experimental & 44 & 22.07 & 1 & 7.942 & $0.006^{*}$ \\
\hline Control & 56 & 25.61 & & & \\
\hline \multicolumn{6}{|l|}{ Fifth grade math } \\
\hline Experimental & 44 & 23.75 & 1 & 19.973 & $0.000^{*}$ \\
\hline Control & 57 & 30.37 & & & \\
\hline
\end{tabular}

${ }^{2}$ Students received a raw score on the test instrument ranging from 0 to 40 based on their answers with each correct answer receiving one point.

${ }^{*}$ Significant at $P \leq 0.05$.

found in comparisons of fourth grade math TAKS scores (Table 4).

Additionally, results indicated that the gardening curriculum was not an effective supplementary tool for teaching fifth grade math and science students. Statistically significant differences showed that fifth grade students learning from traditional curriculum techniques achieved higher math TAKS scores and science achievement scores in comparison to students participating in the gardening program $(P<0.01$; a difference of 3.54 points in science scores, and 6.62 points in math scores, respectively) (Table $4)$. These results differ from results reported by Klemmer et al. (2005), which stated that science achievement scores improved for boys in the third and fifth grades, and girls in the fifth grade, who participated in a gardening curriculum in addition to traditional teaching techniques. From these differences reported in similar studies, it is evident that further research needs to be conducted on school garden programs and their influence on the academic success of students.

\section{Conclusions}

Hands-on learning has been shown to be an important component in promoting positive attitudes toward science (Kyle et al., 1998). Involving children in experiential learning is known to help promote higher-level learning (Donivan, 1993; Markle, 1991; Waliczek et al., 2003). School gardens can be incorporated into curricula as an affordable experiential learning tool for elementary schools. Results from this study support the idea that for some students, gardening may be an effective tool to supplement, enhance, or complement existing traditional curricula. However, these results also indicate that garden curriculum activities may need more development of particular subject areas if they are intended to improve achievement scores such as math and science.

\section{Literature cited}

American Association for the Advancement of Science. 1990. Project 2061: Science for all Americans. Oxford Univ, Press, New York.

Bachert, R. 1976. History and analysis of the school garden movement in America, 18901910. PhD Diss., Dept. of Recreation and Parks Administration, Indiana Univ., Bloomington.

Bassett, T.J. 1979. Vacant lot cultivation: Community gardening in America, 1892-1978. Masters Thesis, Univ. of California, Berkeley.

Braun, J., M. Kotar, and J. Irick. 1989. Cultivating and integrated curriculum: The school garden. Social Studies Young Learner $\mathrm{l}(3): 19-22$
Donivan, M. 1993. A dynamic duo takes on science. Sci. Children 31(2):29-32.

Driver, R., J. Leach, R. Millar, and P. Scott. 1996. Young people's images of science. Open Univ. Press, Buckingham, U.K.

Eames-Sheavly, M. 1999. Sowing the seeds of success: How to start and sustain a kids' gardening project in your community. Natl. Gardening Assn., Burlington, Vt.

Klemmer, C., T.M. Waliczek, and J.M. Zajicek. 2005. Growing minds: The effect of school gardening programs on the science achievement of elementary students. Hort Technology $15(3): 448-457$

Kyle, W., R. Bonnstetter, and T. Gadsen. 1998. An implementation study: An analysis of elementary students' and teachers' attitudes toward science in process approach vs. traditional science classes. J. Res. Sci. Teaching 25(2):103-120.

Lineberger, S.E. and J. Zajicek. 2000. School gardens: Can a hands-on teaching tool affect students' attitudes and behaviors regarding fruits and vegetables? HortTechnology $10(3): 593-597$

Loucks-Horsley, S., R. Kapitan, M. Carlson, P. Kuerbis, R. Clark, G.M. Melle, T. Sachse, and W. Walton. 1990. Elementary school science for the '90s. The Network, Inc., Andover, Mass.

Markle, S. 1991. Green growers: Study soil, seeds, and sprouts, and learn how to grow a great garden. Instructor 100(7):48-51.

Montessori, M. 1912. The Montessori method. Schocken, New York.

National Center for Education Statistics. 2003. Digest of education statistics tables and figures 2003. 12 Feb. 2006. <http://nces.ed.gov/programs/digest $/ \mathrm{d} 03 />$.

National Research Council. 1996. National science education standards. Natl. Academy Press, Washington, D.C.

Skelly, S. and J. Bradley. 2000. The importance of school gardens as perceived by Florida elementary school teachers. HortTechnology $10(1): 1-3$.

Skelly, S.M. and J. Zajicek. 1998. The effect of an interdisciplinary garden program on the environmental attitudes of elementary school students. HortTechnology 8(4):579-583.

Stetson, E. 1991. The big green schoolhouse. Educ. Leadership 18(1):34-35.

Texas Agriculture Extension Service. 2001. Junior Master Gardener ${ }^{\mathrm{TM}}$ health and nutrition from the garden, teacher/leader guide, Level 1. Texas Agr. Ext. Serv., College Station.

Texas Education Agency. 2005. Texas Education Agency, resources for researchers. 19 Dec. 2005. <http://www.tea.state.tx.us/student.assessment/researchers.htmlwww.tea.state.tx.us>.

Waliczek, T.M., P. Logan, and J.M. Zajicek. 2003. Exploring the impact of outdoor environmental activities on children using a qualitative text data analysis system. HortTechnology 13(4):684-688. 